\title{
Quercetin acts as an antioxidant and downregulates CYP1A1 and CYP1B1 against DMBA-induced oxidative stress in mice
}

\author{
EUN JEONG CHOI ${ }^{1}$, TAEHEE KIM ${ }^{2}$ and GUN-HEE KIM ${ }^{1}$ \\ ${ }^{1}$ Plant Resources Research Institute, Duksung Women's University, Seoul 132-714; ${ }^{2}$ Biochemistry Laboratory, \\ College of Pharmacy, Sookmyung Women's University, Seoul 140-742, Republic of Korea
}

Received January 9, 2012; Accepted February 13, 2012

DOI: $10.3892 / o r .2012 .1753$

\begin{abstract}
We investigated the effects of quercetin on 7,12-dimethylbenz(a)anthracene (DMBA)-induced oxidative stress and the expression of CYP1A1 and CYP1B1 in mice. Quercetin was administered orally to mice at 100 or $250 \mathrm{mg} / \mathrm{kg}$ BW for 18 days, after which DMBA (34 mg/kg BW) was administered intragastrically twice. Quercetin showed side effects such as increased aspartate aminotransferase (AST) and alanine aminotransferase (ALT) in DMBA-untreated mice. Also, quercetin induced AST and ALT in DMBA-treated, although this was not significantly different from levels in DMBA-treated controls. The thiobarbituric acid reactive substances (TBARS) value showed a tendency to decrease following quercetin treatment; these decreases were significantly greater in the DMBA-treated compared to the untreated groups. Also, catalase and superoxide dismutase (SOD) activities as well as their mRNA expression were increased by quercetin; this increase was more pronounced in DMBA-treated compared to untreated mice. DMBA induced CYP1 activity as well as expression of CYP1A1 and CYP1B1. Each of these effects was significantly reduced by quercetin; however, this reduction was observed for CYP1A1 at only the higher dose and for CYP1B1 at both doses. These data suggest that quercetin shows antioxidant activity against DMBA-induced oxidative stress. Moreover, its regulation of CYP1A1 and CYP1B1 suggests the potential of quercetin as an anticancer supplement.
\end{abstract}

\section{Introduction}

Quercetin (3,3',4',5,7-pentahydroxyflavone), a member of the flavone family, is found in many foods, including vegetables, tea, fruit and wine (1-3). Several epidemiological studies have supported the hypothesis that the antioxidant action of quer-

Correspondence to: Dr Eun Jeong Choi, Plant Resources Research Institute, Duksung Women's University, 419 Ssangmun-dong, Tobong-ku, Seoul 132-714, Republic of Korea

E-mail: ejchoi@duksung.ac.kr

Key words: antioxidant, aryl hydrocarbon receptor, CYP1A1, CYP1B1, quercetin, mice cetin may reduce the risk of developing cancer $(4,5)$. Based on its anti- and prooxidant activities, two anticancer mechanisms of quercetin have been proposed. First, quercetin can scavenge reactive oxygen species (ROS) as an antioxidant and thereby reduce DNA damage $(6,7)$. In addition, quercetin has been shown to affect the cytochrome P450 (CYP) system, which is one of the main sources of ROS generation in the cell $(8,9)$. On the other hand, quercetin can generate ROS by autoxidation and redox-cycling and so act as a prooxidant $(10,11)$. Several researchers have suggested that the biphasic functions of quercetin may be explained by a concentration-dependent effect; that is, antioxidant activity occurs at lower concentrations than the prooxidant activity (12-14). Our previous report also suggests that quercetin may act not only as an antioxidant, but also as a prooxidant $(15,16)$. The prooxidant activity of quercetin is now becoming accepted as contributing to cancer chemotherapy and inhibition of tumor growth, and increasing evidence suggests that quercetin shows specific inhibition of cancer cell growth (17-19). Consistent with that finding, our report indicated that quercetin significantly inhibited cellular proliferation and induced cell cycle arrest and apoptosis in human breast cancer in vivo (20) and in vitro (21).

In the present study, we focused on the anti- or prooxidant effect of chronic quercetin administration at high doses under oxidative stress condition, i.e., mice treated with 7,12-dimethylbenz(a)anthracene (DMBA). As a potent procarcinogen, DMBA requires metabolic conversion to its ultimate carcinogenic metabolites by oxidation, which is conducted by CYP1A1, CYP1A2 and CYP1B1 (22). In addition, DMBA induces substantial oxidative damage as a result of the formation of ROS such as peroxides, hydroxyl, and superoxide anion radicals in organs such as the liver and mammary glands $(23,24)$.

\section{Materials and methods}

Quercetin treatment and sample preparation. Female ICR mice (23-25 g; Central Laboratory Animal Inc., Seoul, Korea) were housed in groups of three in polypropylene cages $\left(22 \pm 2^{\circ} \mathrm{C}, 40-50 \%\right.$ relative humidity) under controlled lighting (12-h light/dark cycle). Mouse were fed an AIN-93M diet (Dyets, Bethlehem, PA, USA) and allowed free access to water. After an acclimation period, mice were divided into two groups, one of which was maintained on a vehicle and another that was intragastrically administered a dose of $34 \mathrm{mg}$ 
Table I. Food intake and body weight.

\begin{tabular}{lcrl}
\hline Group classification & Food intake (g/day) & Initial body weight $(\mathrm{g})$ & Final body weight ( \\
\hline DMBA-untreated mice & & & $30.5 \pm 2.31$ \\
$0 \mathrm{mg} / \mathrm{kg}$ quercetin & $3.54 \pm 0.52$ & $24.3 \pm 1.1$ & $31.2 \pm 3.36$ \\
$100 \mathrm{mg} / \mathrm{kg}$ quercetin & $4.01 \pm 0.36$ & $25.3 \pm 1.0$ & $29.5 \pm 3.42$ \\
$250 \mathrm{mg} / \mathrm{kg}$ quercetin & $3.46 \pm 0.41$ & $23.6 \pm 1.1$ & \\
DMBA-treated mice & & & $28.2 \pm 3.36$ \\
$0 \mathrm{mg} / \mathrm{kg}$ quercetin & $3.46 \pm 0.58$ & $24.3 \pm 1.0$ & $31.5 \pm 3.28$ \\
$100 \mathrm{mg} / \mathrm{kg}$ quercetin & $3.53 \pm 0.63$ & $24.5 \pm 1.0$ & $27.6 \pm 4.32$ \\
$250 \mathrm{mg} / \mathrm{kg}$ quercetin & $3.39 \pm 0.41^{\mathrm{a}}$ & $25.4 \pm 0.9$ &
\end{tabular}

Mice were divided into two groups, one was maintained on a vehicle and the other that was intragastrically administered DMBA. Subsequently, each group was subdivided randomly into three treatment groups, two of which received quercetin at $100 \mathrm{and} 250 \mathrm{mg} / \mathrm{kg}$ body weight for 18 days. Values are the mean $\pm \mathrm{SD}(\mathrm{n}=5-7)$. ${ }^{\mathrm{a}}<0.05$, significantly different from the respective control group (DMBA-treated or untreated).

DMBA/kg body weight (BW) in corn oil vehicle twice a week. Subsequently, each group was subdivided randomly into three treatment groups. Quercetin (Sigma-Aldrich, St. Louis, MO, USA) was dissolved in corn oil and administered orally to two of the three groups at 100 and $250 \mathrm{mg} / \mathrm{kg}$ body weight for 18 days, respectively. Mice were treated with quercetin or the vehicle and weighed at the same time (7 to $8 \mathrm{am}$ ) every morning for 18 days. Quercetin was stored in a refrigerator. Quercetin suspension was freshly prepared once every three day based on the body weight of the animals and stored at $-4^{\circ} \mathrm{C}$ to $0^{\circ} \mathrm{C}$ until used. Animal care in this study conformed to the Guide for the Care and Use of Laboratory Animals published by the USA National Institutes of Health.

At the end of the experiment, mice were rapidly anesthetized using ether at $6 \mathrm{~h}$ after final administration of quercetin. After blood was taken from the heart by heart puncture, serum was obtained by centrifuging the blood at 2,500 rpm for $15 \mathrm{~min}$. Aspartate aminotransferase (AST) and alanine aminotransferase (ALT) contents were determined by the Advia 1650 chemistry analyzer (Siemens Medical Solutions Diagnostics, Norwood, MA, USA) using appropriate kits (Bayer). In addition, their livers were isolated, blotted, weighed, frozen in liquid nitrogen and stored at $-70^{\circ} \mathrm{C}$ until assayed. Each sample homogenate was centrifuged at $800 \mathrm{x} \mathrm{g}$ to remove cell debris and nuclei; the supernatants were centrifuged at $10,000 \mathrm{x} \mathrm{g}$ for $10 \mathrm{~min}$ and the portions of the post-mitochondrial fraction were transferred. To obtain the cytosolic fractions for superoxide dismutase (SOD) activity measurement, the remaining supernatant was centrifuged further at 105,000 x $\mathrm{g}$ for $45 \mathrm{~min}$ using a 50 Ti Rotor in a Beckman model L90 ultracentrifuge. Post-mitochondrial and cytosolic fractions were stored at $-80^{\circ} \mathrm{C}$ in aliquots until analysis within one week.

Determination of oxidative stress biomarkers and activity of antioxidant enzymes. The TBARS (thiobarbituric acid reactive substances) value was determined by measuring the concentration of malondialdehyde according to the method of Ohkawa et al (25) and calculated according to the molar absorption coefficient of malondialdehyde (MDA), $\varepsilon=1.56 \times 10^{5} \mathrm{M}^{-1} \mathrm{~cm}^{-1}$ at $535 \mathrm{~nm}$. Catalase activity was assayed by the method of
Aebi (26) and was expressed as $\mathrm{nmol} / \mathrm{min} / \mathrm{mg} /$ protein of decomposed $\mathrm{H}_{2} \mathrm{O}_{2}$. SOD activity was assayed according to the pyrogallol autoxidation method of Marklund and Marklund (27). Each unit of SOD activity was defined as the quantity of enzyme that inhibited autoxidation of pyrogallol by $50 \%$ under experimental conditions.

Assay of CYP enzyme activity. CYP activity was determined by formation of resorufin (Sigma) from ethoxyresorufin. Microsomal proteins (100-250 $\mu \mathrm{g}$ ) were mixed with $100 \mathrm{mM}$ phosphate buffer ( $\mathrm{pH} 7.4$ ) and 1-2 $\mu \mathrm{M}$ of 7-ethoxyresorufin. The reaction was initiated by the addition of $0.50 \mathrm{mM}$ NADPH and was incubated at $37^{\circ} \mathrm{C}$ for $10 \mathrm{~min}$ and scanned in the microtiter plate fluorescent reader. The reaction was stopped by the addition of methanol, and then after centrifugation. The amount of resorufin formed was quantified from a standard curve constructed with known amounts of resorufin. The excitation and emission wavelengths for the detection of resorufin were 530 and $590 \mathrm{~nm}$, respectively.

Immunoblotting assay. Proteins (30 $\mu \mathrm{g} /$ well) denatured with sample buffer were separated by $10 \%$ SDS-polyacrylamide gel electrophoresis. Proteins were transferred onto nitrocellulose membranes $(0.45 \mu \mathrm{m})$. The membranes were blocked with a $1 \%$ BSA solution for $3 \mathrm{~h}$ and washed twice with PBS containing $0.2 \%$ Tween-20, and incubated with the primary antibody overnight at $4^{\circ} \mathrm{C}$. Antibodies against catalase, CuZn-, Mn-SOD, CYP1A1, CYP1B1, aryl hydrocarbon receptor $(\mathrm{AhR})$ and $\beta$-actin were purchased from Santa Cruz Biotechnology, Inc., (Santa Cruz, CA, USA) and used to probe the separate membranes. The next day, the immunoreaction was continued with a secondary goat anti-rabbit horseradishperoxidase-conjugated antibody after washing for $2 \mathrm{~h}$ at room temperature. The specific protein bands were detected by Opti-4CN Substrate kit (Bio-Rad Laboratories, Inc., Hercules, CA, USA).

Statistical analyses. All data were expressed as percent compared with vehicle-treated control, which were arbitrarily assigned $100 \%$. All values are expressed as mean \pm SD. Data 


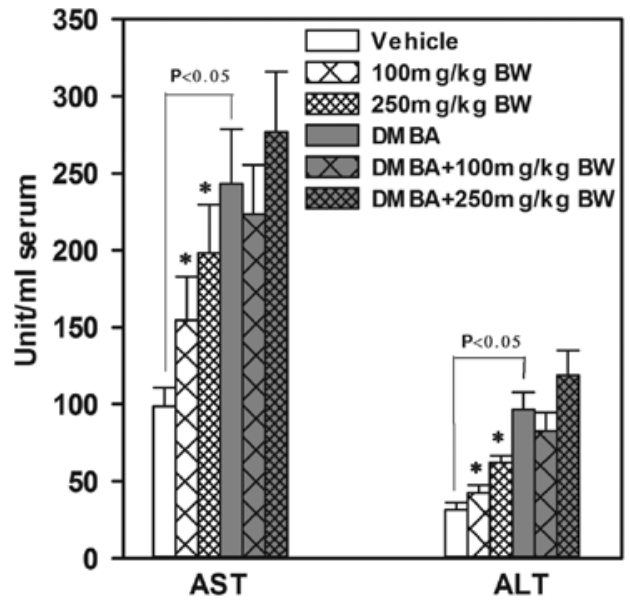

Figure 1. Effect of quercetin administration on serum AST and ALT levels. Values are mean $\pm \mathrm{SD}(\mathrm{n}=5-7)$. ${ }^{*} \mathrm{P}<0.05$, significantly different from the respective control group (DMBA-treated or untreated).

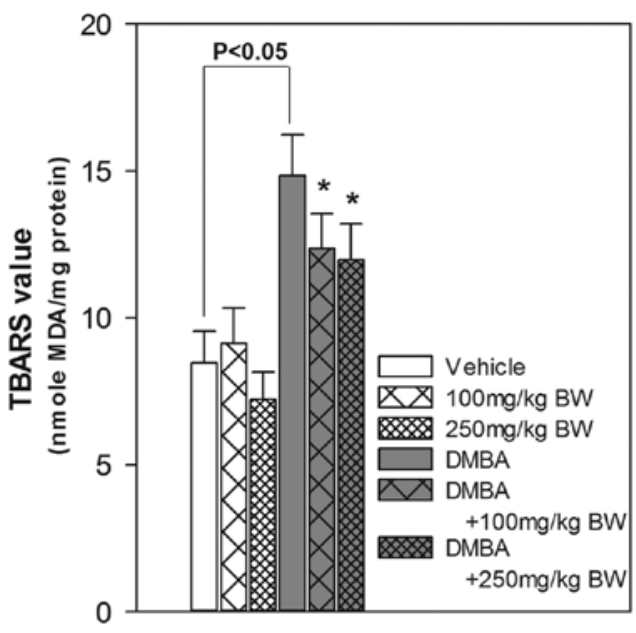

Figure 2. Effect of quercetin administration on hepatic TBARS values. Values are mean $\pm S D(n=5-7) .{ }^{*} \mathrm{P}<0.05$, significantly different from the respective control group (DMBA-treated or untreated).

were analyzed by the unpaired Student's t-test or one-way analysis of variance followed by the Dunnett's multiple comparison test (SigmaStat, Jandel, San Rafael, USA). For all comparisons, differences were considered statistically significant at $\mathrm{P}<0.05$.

\section{Results}

Food intake and body weight. Although no statistically significant differences were recorded between DMBA-untreated and DMBA-treated mice in food intake and body weight gain, DMBA induced a $9.2 \%$ decrease in final body weight compared to DMBA-uhtreated controls (Table I). Also, quercetin at the higher dose caused a non-significant decrease in the final body weight in both DMBA-untreated and -treated mice.

Serum AST and ALT levels and hepatic TBARS value. Serum AST and ALT levels were significantly increased by 2.5- and 3.1-fold DMBA-treated and -untreated control mice, respec-
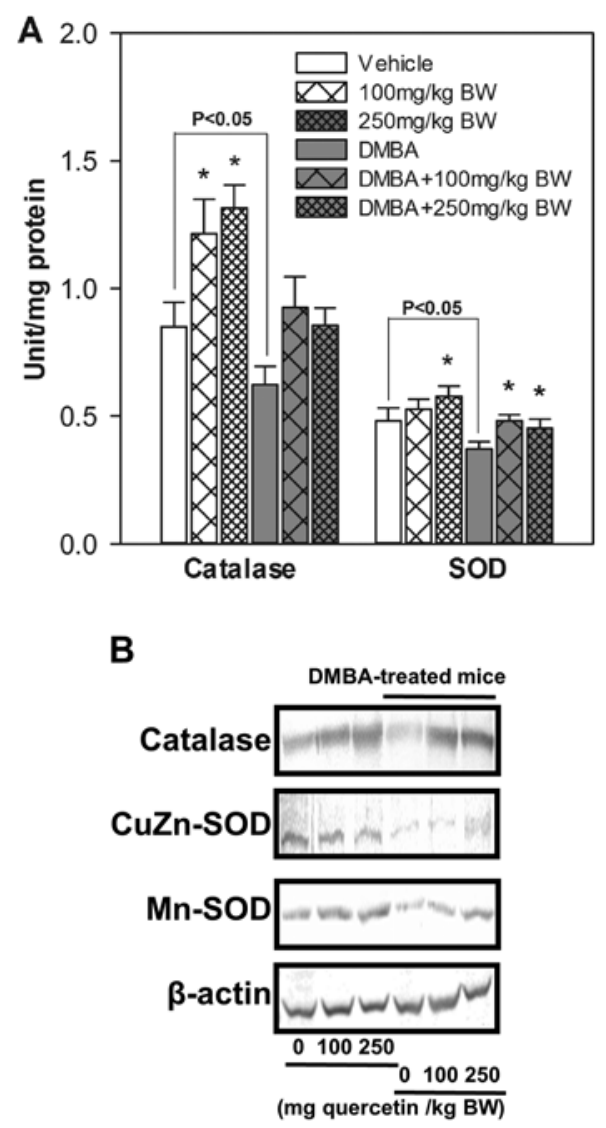

Figure 3. Activities (A) of catalase and total SOD, and its protein expression (B). Values are mean $\pm \mathrm{SD}(\mathrm{n}=5-7)$. ${ }^{*} \mathrm{P}<0.05$, significantly different from the respective control group (DMBA-treated or untreated).

tively (Fig. 1). Although quercetin administration significantly increased AST and ALT levels in a dose-dependent manner in DMBA-untreated mice, quercetin at the lower $(100 \mathrm{mg} / \mathrm{kg}$ $\mathrm{BW})$, but not the higher dose $(250 \mathrm{mg} / \mathrm{kg} \mathrm{BW})$ inhibited both AST and ALT (8.2 and 14.2\% inhibition) in DMBA-treated mice, which was increased by DMBA. DMBA-treated mice given quercetin at the higher dose showed 13.6 and $23.0 \%$ increase in ALT and AST levels, respectively, although this difference was not significant.

The hepatic TBARS value of DMBA-treated mice was significantly $(\mathrm{P}<0.05)$ greater than that of untreated mice $(8.47$ and $14.85 \mathrm{nmol} / \mathrm{mg}$ protein, respectively, Fig. 2). Quercetin at both doses significantly decreased the TBARS value in DMBAtreated mice, but not untreated mice (16.7 and $19.4 \%$ decreases at 100 and $250 \mathrm{mg} / \mathrm{kg} \mathrm{BW}$, respectively, $\mathrm{P}<0.05)$. Although quercetin at the higher dose $(250 \mathrm{mg} / \mathrm{kg} \mathrm{BW})$ decreased the TBARS value in DMBA-untreated mice (14.6\% compared to the control group), this difference was not significant.

Activity and expression of the antioxidant defense enzymes, catalase and total SOD. The hepatic catalase activity in DMBA-treated mice was significantly $(\mathrm{P}<0.05)$ lower than in untreated mice $(0.62$ and $0.85 \mathrm{U} / \mathrm{mg}$ protein, respectively, Fig. 3A). Quercetin increased catalase activity in all mice (both of DMBA-untreated and -treated) regardless of quercetin. Total SOD activities in DMBA-treated mice were also significantly $(\mathrm{P}<0.05)$ decreased by about $23 \%$ compared to those of untreated control mice. Although quercetin had no 


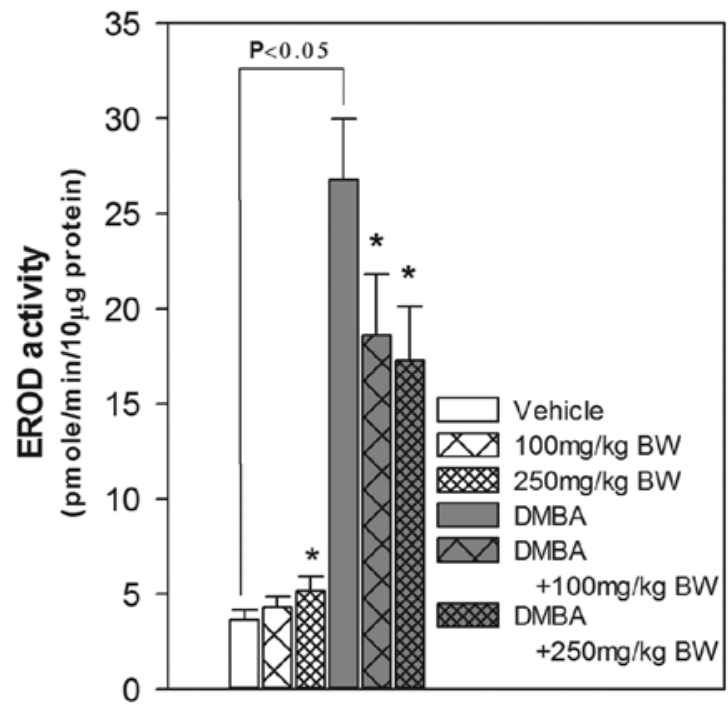

Figure 4. Effect of quercetin administration on ethoxyresorufin O-deethylase (EROD) activity. Values are mean $\pm \mathrm{SD}(\mathrm{n}=5-7)$. ${ }^{*} \mathrm{P}<0.05$, significantly different from the respective control group (DMBA-treated or untreated).

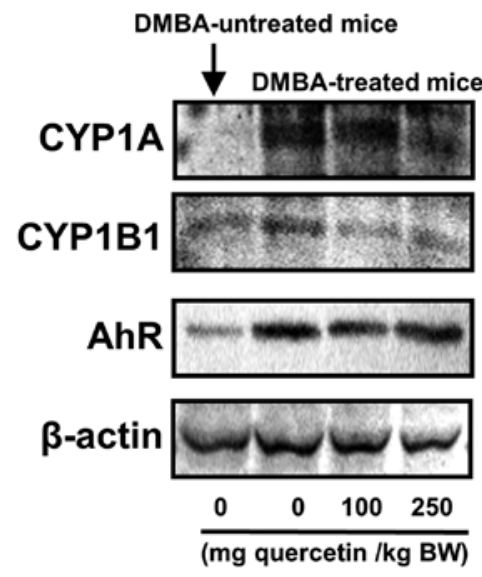

Figure 5. Effect of quercetin administration on expression of CYP1A1, CYP1B1 and AhR in DMBA-treated mice.

significant affect under normal conditions, the decreased total SOD in DMBA-treated mice returned to normal levels after quercetin administration.

A similar pattern was evident for the protein expression (Fig. 3B). Increases in Mn-SOD expression by quercetin were more pronounced than those of CuZn-SOD in DMBA-treated mice.

Ethoxyresorufin O-deethylase (EROD) activity and CYPIAl, $C Y P 1 B 1$ and AhR expression. The basal activity of EROD in DMBA-treated mice was significantly greater than that in untreated controls $(26.78$ and $3.65 \mathrm{pmol} / \mathrm{min} / 10 \mu \mathrm{g}$ protein, Fig. 4). Quercetin non-significantly increased EROD activity in normal mice, while the increased EROD level caused by DMBA was significantly decreased by quercetin (by 30.5 and $35.5 \%$ with 100 and $250 \mathrm{mg} / \mathrm{kg}$ quercetin, respectively).

To verify EROD activity, the effect of quercetin on CYP1A1, CYP1B1 and AhR expression was quantified in DMBA-treated mice (Fig. 5). In control mice, CYP1A1, CYP1B1, and AhR expressions were dramatically increased compared to those of DMBA-untreated mice. Activated CYP1A1 was decreased after quercetin administration at the higher dose and CYP1B1 was decreased in both doses. AhR expression was not affected by quercetin administration.

\section{Discussion}

Quercetin is one of the most abundant and most powerful antioxidant of over 6,000 flavonoids. Recently, the role of quercetin has been suggested to depend on its concentration and exposure period $(12,15)$. Moreover, its safety remains controversial because several studies have warned that the use of quercetin at high concentrations has deleterious effects.

In the present study, the dose of quercetin used (100 and $250 \mathrm{mg} / \mathrm{kg}$ BW/day) was much higher than that found in human foods, which typically contain $1-10 \mathrm{mg} / \mathrm{g}$ edible plant matter (28-30). Administration of quercetin resulted in significant increases in serum AST and ALT levels. These may have resulted from leakage of these enzymes into the circulation, and may indicate liver damage and altered liver function $(31,32)$. However, quercetin $(100 \mathrm{mg} / \mathrm{kg} \mathrm{BW})$ in mice treated with DMBA decreased serum AST and ALT levels, although this difference was not significant.

Oxidative stress produces deleterious effects by initiating lipid peroxidation either directly or by acting as second messengers for the primary free radicals that initiate lipid peroxidation (33). The TBARS value (a biomarker of lipid peroxidation) was significantly higher in the DMBA-treated group than in the untreated control group. This is consistent with previous reports stating that DMBA induces critical oxidative damage in the liver in vivo (34-36). Even though quercetin did not reduce the TBARS value of DMBA-untreated mice to normal levels, quercetin has previously been shown to inhibit lipid peroxidation.

SOD is the first and most important line of antioxidant enzyme defense against oxidative stress, particularly oxygen radicals. SOD scavenges superoxide by converting it to peroxide, which is then destroyed by catalase (37). Catalase and total SOD activity were significantly decreased in DMBAtreated mice compared to untreated controls, suggesting the induction of oxidative stress by DMBA. The reduced catalase and total SOD activities were increased by quercetin administration to normal levels (DMBA-untreated control). This trend was also observed in the expression of catalase and SOD (Mn- and $\mathrm{CuZn}-\mathrm{SOD}$ ).

Based on these results, although quercetin acts as an antioxidant by either decreasing TBARS or increasing catalase and SOD activities, chronic high consumption results in obvious side effects. One possible explanation is that quercetin at higher doses may be more active under conditions of oxidative stress. A natural dynamic balance exists between the amount of free radicals generated and the antioxidant defense system, which protects the body against carcinogenesis (38). Many antioxidants have been studied for possible use as anticancer agents. Evidence exists that flavonoids can enhance the detoxification of carcinogens and decrease DNA damage $(39,40)$. Thus, notwithstanding some side effects, quercetin at higher doses under DMBA-induced oxidative stress conditions may have potential as an antioxidant agent. 
DMBA is a polycyclic aromatic hydrocarbon (PAHs) and is oxidized by CYP1A1 and CYP1B1 in the liver to form carcinogenic metabolites, including diol epoxides and other toxic reactive oxygen radicals $(41,42)$. In vitro experiments indicate that DMBA in rat liver microsomes causes dose- and timedependent production of $\mathrm{H}_{2} \mathrm{O}_{2}$, an oxidant closely associated with tumor promotion $(43,44)$. The induction of such CYP1 family members as CYP1A1, 1A2, and 1B1 is regulated by the aryl hydrocarbon receptor (AhR) and the AhR nuclear translocator (ARNT).

Consistent with these facts, the expression of CYP1A1 and CYP1B1 in DMBA-treated mice was dramatically increased. A similar pattern was observed in EROD activity, which was used to determine the level of CYP activity. DMBA strongly induced EROD activity in DMBA-treated mice as well as expression of CYP1A1, CYP1B1 and AhR. The induction of CYP1 family members such as CYP1A1, 1A2 and 1B1 is regulated by AhR $(45,46)$. Quercetin was reported to significantly downregulate the CYP system both in vitro (47-49) and in vivo $(50,51)$. The increase in CYP1A1 and CYP1A2 levels induced by oxidative products was inhibited by quercetin (47-49). In the present study, as a result of quercetin administration at the higher dose (200 mg), CYP1A1 and CYP1B1, but not AhR, levels, were significantly decreased. These results suggest that downregulation of CYP1A1 by quercetin is irrelevant to the regulation of AhR in mice treated with DMBA. Thus, quercetin has the potential to be applied as a chemotherapeutic agent, since the discovery of molecules able to modulate the activity of specific CYP isomers is a major goal in the development of chemotherapeutics.

In summary, the study demonstrated that chronic administration of high-dose quercetin may have a dual effect. The regular consumption of quercetin-enriched supplements should be monitored carefully because of their potential side effects. Nevertheless, the activation of antioxidant-related enzymes and regulation of CYPs by quercetin under oxidative stress conditions shows the possibility of quercetin as an anticancer chemotherapeutic without causing side effects.

\section{Acknowledgements}

This research was supported by the Basic Research Program through the National Research Foundation of Korea (NRF) funded by the Ministry of Education, Science and Technology (2011-0026172 and 2011-0031386).

\section{References}

1. Hertog MG, Hollman PC, Katan M and Kromhout D: Intake of potentially anticarcinogenic flavonoids and their determinants in adults in The Netherlands. Nutr Cancer 20: 21-29, 1993.

2. Hertog MG, Bueno-de-Mesquita HB, Fehily AM, Sweetnam PM, Elwood PC and Kromhout D: Fruit and vegetable consumption and cancer mortality in the Caerphilly Study. Cancer Epidemiol Biomarkers Prev 5: 673-677, 1996.

3. Frankel EN, Kanner J, German JB, Parks E and Kinsella JE: Inhibition of oxidation of human low-density lipoprotein by phenolic substances in red wine. Lancet 341: 454-457, 1993.

4. Neuhouser ML: Dietary flavonoids and cancer risk: evidence from human population studies. Nutr Cancer 50: 1-7, 2004.

5. Peeters PH, Keinan-Boker L, van der Schouw YT and Grobbee DE: Phytoestrogens and breast cancer risk. Review of the epidemiological evidence. Breast Cancer Res Treat 77: 171-183, 2003
6. Vaquerizo-Madrid J: Hyperactivity in preschoolers: a clinical description. Rev Neurol 40: S25-S32, 2005 (In Spanish).

7. Metodiewa D, Jaiswal AK, Cenas N, Dickancaité E and Segura-Aguilar J: Quercetin may act as a cytotoxic prooxidant after its metabolic activation to semiquinone and quinoidal product. Free Radic Biol Med 26: 107-116, 1999.

8. Bondy SC and Naderi S: Contribution of hepatic cytochrome P450 systems to the generation of reactive oxygen species. Biochem Pharmacol 48: 155-159, 1994.

9. Puntarulo $\mathrm{S}$ and Cederbaum AI: Production of reactive oxygen species by microsomes enriched in specific human cytochrome P450 enzymes. Free Radic Biol Med 24: 1324-1330, 1998.

10. Briante R, Febbraio F and Nucci R: Antioxidant/prooxidant effects of dietary non-flavonoid phenols on the $\mathrm{Cu}^{2+}$-induced oxidation of human low-density lipoprotein (LDL). Chem Biodivers 1: 1716-1729, 2004.

11. Galati G, Sabzevari O, Wilson JX and O'Brien PJ: Prooxidant activity and cellular effects of the phenoxyl radicals of dietary flavonoids and other polyphenolics. Toxicology 177: 91-104, 2002.

12. Wätjen W, Michels G, Steffan B, Niering P, Chovolou Y, Kampkötter A, Tran-Thi QH, Proksch P and Kahl R: Low concentrations of flavonoids are protective in rat H4IIE cells whereas high concentrations cause DNA damage and apoptosis. J Nutr 135: 525-531, 2005.

13. Robaszkiewicz A, Balcerczyk A and Bartosz G: Antioxidative and prooxidative effects of quercetin on A549 cells. Cell Biol Int 31: 1245-1250, 2007.

14. van der Woude H, Gliszczyńska-Swigło A, Struijs K, Smeets A, Alink GM and Rietjens IM: Biphasic modulation of cell proliferation by quercetin at concentrations physiologically relevant in humans. Cancer Lett 200: 41-47, 2003.

15. Choi EJ, Chee KM and Lee BH: Anti- and prooxidant effects of chronic quercetin administration in rats. Eur J Pharmacol 482: 281-285, 2003.

16. Choi EJ, Lee BH, Lee K and Chee KM: Long-term combined administration of quercetin and daidzein inhibits quercetininduced suppression of glutathione antioxidant defenses. Food Chem Toxicol 43: 793-798, 2005.

17. Ishizawa K, Izawa-Ishizawa Y, Ohnishi S, Motobayashi Y, Kawazoe K, Hamano S, Tsuchiya K, Tomita S, Minakuchi K and Tamaki T: Quercetin glucuronide inhibits cell migration and proliferation by platelet-derived growth factor in vascular smooth muscle cells. J Pharmacol Sci 109: 257-264, 2009.

18. Notoya M, Tsukamoto Y, Nishimura H, Woo JT, Nagai K, Lee IS and Hagiwara H: Quercetin, a flavonoid, inhibits the proliferation, differentiation, and mineralization of osteoblasts in vitro. Eur J Pharmacol 485: 89-96, 2004.

19. Ramos AA, Lima CF, Pereira ML, Fernandes-Ferreira M and Pereira-Wilson C: Antigenotoxic effects of quercetin, rutin and ursolic acid on HepG2 cells: evaluation by the comet assay. Toxicol Lett 177: 66-73, 2008.

20. Choi EJ and Kim GH: Quercetin accumulation by chronic administration causes the caspase-3 activation in liver and brain of mice. Biofactors 36: 216-221, 2010.

21. Choi EJ, Bae SM and Ahn WS: Antiproliferative effects of quercetin through cell cycle arrest and apoptosis in human breast cancer MDA-MB-453 cells. Arch Pharm Res 31: 1281-1285, 2008.

22. Shou M, Korzekwa KR, Krausz KW, Buters JT, Grogan J, Goldfarb I, Hardwick JP, Gonzalez FJ and Gelboin HV: Specificity of cDNA-expressed human and rodent cytochrome P450s in the oxidative metabolism of the potent carcinogen 7,12-dimethylbenz[a]anthracene. Mol Carcinog 17: 241-249, 1996.

23. Izzotti A, Camoirano A, Cartiglia C, Grubbs CJ, Lubet RA, Kelloff GJ and De Flora S: Patterns of DNA adduct formation in liver and mammary epithelial cells of rats treated with 7,12-dimethylbenz(a)anthracene, and selective effects of chemopreventive agents. Cancer Res 59: 4285-4290, 1999.

24. Anbuselvam C, Vijayavel K and Balasubramanian MP: Protective effect of Operculina turpethum against 7,12-dimethyl benz(a) anthracene induced oxidative stress with reference to breast cancer in experimental rats. Chem Biol Interact 168: 229-236, 2007.

25. Ohkawa H, Ohishi $\mathrm{N}$ and Yagi K: Assay for lipid peroxides in animal tissues by thiobarbituric acid reaction. Anal Biochem 95: 351-358, 1979.

26. Aebi H: Catalase in vitro. Methods Enzymol 105: 121-126, 1984. 
27. Marklund S and Marklund G: Involvement of the superoxide anion radical in the autoxidation of pyrogallol and a convenient assay for superoxide dismutase. Eur J Biochem 47: 469-474, 1974.

28. Häkkinen SH, Kärenlampi SO, Heinonen IM, Mykkänen HM and Törrönen AR: Content of the flavonols quercetin, myricetin, and kaempferol in 25 edible berries. J Agric Food Chem 47: 2274-2279, 1999

29. Miean KH and Mohamed S: Flavonoid (myricetin, quercetin kaempferol, luteolin, and apigenin) content of edible tropical plants. J Agric Food Chem 49: 3106-3112, 2001

30. Pastrana-Bonilla E, Akoh CC, Sellappan S and Krewer G: Phenolic content and antioxidant capacity of muscadine grapes. J Agric Food Chem 51: 5497-5503, 2003.

31. Yousef MI, Awad TI and Mohamed EH: Deltamethrin-induced oxidative damage and biochemical alterations in rat and its attenuation by vitamin E. Toxicology 227: 240-247, 2006.

32. Devipriya S, Ganapathy V and Shyamaladevi CS: Suppression of tumor growth and invasion in 9,10 dimethyl benz(a) anthracene induced mammary carcinoma by the plant bioflavonoid quercetin. Chem Biol Interact 162: 106-113, 2006.

33. Das U: A radical approach to cancer. Med Sci Monit 8: RA79-RA92, 2002

34. Letchoumy PV, Chandra Mohan KV, Kumaraguruparan R, Hara Y and Nagini S: Black tea polyphenols protect against 7,12-dimethylbenz[a]anthracene-induced hamster buccal pouch carcinogenesis. Oncol Res 16: 167-178, 2006.

35. Chandra Mohan KV, Subapriya R, Hara Y and Nagini S: Enhancement of erythrocyte antioxidants by green and black tea polyphenols during 7,12-dimethylbenz[a]anthracene-induced hamster buccal pouch carcinogenesis. J Med Food 9: 373-377, 2006.

36. Manikandan P, Murugan RS, Abbas H, Abraham SK and Nagini S: Ocimum sanctum Linn. (Holy Basil) ethanolic leaf extract protects against 7,12-dimethylbenz(a)anthracene-induced genotoxicity, oxidative stress, and imbalance in xenobioticmetabolizing enzymes. J Med Food 10: 495-502, 2007.

37. Fridovich I: Superoxide anion radical $\left(\mathrm{O}_{2}^{--}\right)$, superoxide dismutases, and related matters. J Biol Chem 272: 18515-18517, 1997.

38. Kolanjiappan K, Manoharan S and Kayalvizhi M: Measurement of erythrocyte lipids, lipid peroxidation, antioxidants and osmotic fragility in cervical cancer patients. Clin Chim Acta 326: 143-149, 2002

39. Lampe JW: Health effects of vegetables and fruit: assessing mechanisms of action in human experimental studies. Am J Clin Nutr 70: S475-S490, 1999.
40. Middleton E Jr, Kandaswami C and Theoharides TC: The effects of plant flavonoids on mammalian cells: implications for inflammation, heart disease, and cancer. Pharmacol Rev 52: 673-751, 2000.

41. Rowlands JC, He L, Hakkak R, Ronis MJ and Badger TM Soy and whey proteins downregulate DMBA-induced liver and mammary gland CYP1 expression in female rats. J Nutr 131: 3281-3287, 2001.

42. Slaga TJ, Gleason GL, DiGiovanni J, Sukumaran KB and Harvey RG: Potent tumor-initiating activity of the 3,4-dihydrodiol of 7,12-dimethylbenz(a)anthracene in mouse skin. Cancer Res 39: 1934-1936, 1979.

43. Frenkel K, Grunberger D, Kasai H, Komura H and Nakanishi K: Identification of novel 7,12-dimethylbenz[a]anthracene adducts in cellular ribonucleic acid. Biochemistry 20: 4377-4381, 1981.

44. Frenkel K: The role of active oxygen species in biological damage and the effect of some chemopreventive agents. In: Protease Inhibitors as Cancer Chemopreventive Agents. Troll W and Kennedy AR (eds). Plenum Press, New York, pp227-249, 1993.

45. Evans RM: The steroid and thyroid hormone receptor superfamily. Science 240: 889-895, 1988.

46. Kawajiri K and Fujii-Kuriyama Y: Cytochrome P450 gene regulation and physiological functions mediated by the aryl hydrocarbon receptor. Arch Biochem Biophys 464: 207-212, 2007.

47. Yeh SL and Wu SH: Effects of quercetin on beta-apo-8'-carotenal-induced DNA damage and cytochrome P1A2 expression in A549 cells. Chem Biol Interact 163: 199-206, 2006.

48. Kang IH, Kim HJ, Oh H, Park YI and Dong MS: Biphasic effects of the flavonoids quercetin and naringenin on the metabolic activation of 2-amino-3,5-dimethylimidazo[4,5-f]quinoline by Salmonella typhimurium TA1538 co-expressing human cytochrome P450 1A2, NADPH-cytochrome P450 reductase, and cytochrome b5. Mutat Res 545: 37-47, 2004.

49. Bacon JR, Williamson G, Garner RC, Lappin G, Langouët S and Bao Y: Sulforaphane and quercetin modulate PhIP-DNA adduct formation in human HepG2 cells and hepatocytes. Carcinogenesis 24: 1903-1911, 2003

50. Yu CP, Wu PP, Hou YC, Lin SP, Tsai SY, Chen CT and Chao PD: Quercetin and rutin reduced the bioavailability of cyclosporine from Neoral, an immunosuppressant, through activating P-glycoprotein and CYP 3A4. J Agric Food Chem 59: 4644-4648, 2011 .

51. Li X and Choi JS: Effects of quercetin on the pharmacokinetics of Etoposide after oral or intravenous administration of etoposide in rats. Anticancer Res 29: 1411-1415, 2009. 